悪性疾患患者に対する化学療法, 免疫療法, 免疫化学療法

施行前後に於ける細胞性免疫能の変動

一特に胃癌患者を中心に一

東京医科大学外科学第 3 講座（指導教授：牧野惟義）

大学院 田渕崇 文

\title{
FLUCTUATIONS IN CELLULAR IMMUNOABILITY BEFORE AND AFTER CHEMOTHERAPY IMMUNOTHERAPY AND IMMUNOCHEMOTHERAPY OBSERVED IN PATIANTS SUFFERING FROM MALIGNANT DISEASES
}

-Mainly Stomach Cancer-

Graduate Student : Takafumi TABUCHI

3rd Lecture Department of Surgery, Tokyo Medical College

(Instructing Professor : Koreyoshi Makino)

免疫不全状態を背景にしている担癌宿主の細胞性免疫能の变動を観察することは, 治療 の選択，予後判定の一指標となると考え，手術施行担癌患者に5FU，FT-207及び MMC の単独或は併用による化学療法，OK-432k上る免疫療法，さらに両者を併用した免疫化 学療法を胃癌症例63例を中心に計98例に独自のプロトコールにのっとり施行し, 細胞性免 疫能の変動を末梢血 T 細胞, 荤延型皮唐反応で観察した。

I. 実験方法

1） $\mathrm{T}$ 細胞測定：比重1.077の Sodium Metrizoate ficoll を用い，比重遠心法にて分離 したりンパ球をマイクロテストプレート洗にて T細胞とB 細胞に織別した.

2）遅延型皮店反応：PPD 及び PHA を抗原として, 患者前腕に皮内接種し，平均紅 斑径を測定した。

II. 実験結果及び結語

(1) 化学療法により担癌宿主の細胞珄免疫能は低下する.

(2) 多剤化学療法に於いてその㑯向は著明であった.

（3）治芴切除例では，化学療法に上る細胞性免疫能低下は軽微であった。

(4) 免疫療法に上り担癌宿主の細胞性免疫能は保持向上する.

(5) 非切除例及び再発例では，細胞性免疫能の保持向上は殆んど期待できない.

（6) 免疫化学療法です，担癌宿主の細胞性免疫能は保持向上され，化学療法による殺腫 瘍効果と免疫療法に上る免疫賦活効果の相乗効果が期待できる.

(7) いずれの治療法に於いても残存腫瘍の大きい非切除例及び再発例では，その効果は あまり期待できない。

(8) 現状に於いて, 担癌宿主の細胞性免疫能を経時的に観察しつつ, 化学療法に免疫療 法を併用した免疫化学療法が最も有効である. 


\section{第 I章 粠量}

癌の治療は, 従来外科的手術療法, 放射線療法, 化学 療法の 3 大治療法が中心となり, 単独に或は併用によっ てそれなりの効果を挙げてきた. 又近年, 診断技術の著 しい向上により，ょり早期のるのが発見されるよらにな ク，その遠隔成績も向上している. 然し，これらの治療 法に一定の限界があり, 進行癌の 5 年生存率の面から も明らかの如く, 現状に於いてこれ以上の飛躍的治療効 果の向上は期待出来ない. しかし, 近年腫湟免疫学の発 達とともに癌特異抗原 (tumor specific antigen TSA), 尰場関連抗原 (tumor associated antigen) が明らかにな ってきた. しかもこれらの抗原に応答するのは，マク ロファーシ，リンパ球であると考えられてきた。すなわ ら，生じた癌抗原はマクロファージによってまずとらえ られ，リンパ球特に T 細胞の表面の抗原受容体にわた り，リンパ球は刺激をらけ分裂増殖し感作リンパ球が生 じると言われており，この感作リンパ球が癌細胞に近づ $く と$, lymphotoxin mitogenfactor. macrophage inhibitory factor などの諸因子が出され癌細胞を功撃すると考えら れている ${ }^{1 / 2) 3}$. この様に癌の免疫応答は, 細胞性免疫が 主体をなしているが，一方では体液性免疫の関与も主 張されている、しかし，この様な免疫応答が担癌体に生 ずるにもかかからず癌増殖は現実に起っている. その理 由の一つとして, 癌の抗原性が低く,ささに癌細胞から 遊離するある因子によって宿主の一般的免疫応答力の低 下が考えられる. 担癌体の基盤に免疫不全がある限り宿 主の免疫機能改善が望まれ，免疫療法の導入が考えられ てくる，しかも従来行われてきた化学療法では，大なり 小なり免疫系に影響を与克, 時として免疫不全を助長す ることも考えられ，免疫療法の併用を考えねばならな いそこで著者は，癌治療にあたって細胞性兔疫能の動 態を観察することは, 治療の選択, 予後判定の大きな指 標となると考え本研究を行った。

\section{第II 章 実験材料及び方法}

\section{第 1 節 対象应例}

対象症例は, 表 1 左に示す如く, 胃癌症例63例を中心 に計98例につき, 化学療法, 免疫療法, 兔疫化学療法を 施行し，その細胞性免疫能の変動を検討した. これらの 症例は, 進行癌術後及び再発癌であり, 早期癌はその遠 隔成績からしてむ化学療法の対象外と考光除外した. 治 療別にみた症例数は，表 1 右に示す如く，化学療法群37 例, 免疫療法群19例，免疫化学療法群42例である.

第 2 節 投与薬剛及びその投与方法

表 1

症 例 数

\begin{tabular}{cr|c}
\hline 疾 & 患 & 例数 \\
\hline 胃 & 癌 & 63 \\
結腸癌 & 18 \\
肺 & 癌 & 3 \\
食道癌 & 2 \\
胆道癌 & 2 \\
膵臹癌 & 3 \\
乳 癌 & 4 \\
その他 & 3 \\
\hline 計 & 98 \\
\hline
\end{tabular}

\begin{tabular}{c|c|c}
\hline 投 与 & 法 & 例数 \\
\hline \multirow{2}{*}{ 化学療法群 } & F & 19 \\
\cline { 2 - 3 } & $\mathrm{MF}$ & 18 \\
\hline 免疫療法群 & $\mathrm{O}$ & 19 \\
\hline 化 学 療 法 & FO & 19 \\
\cline { 2 - 3 } 免療法群 & MFO & 23 \\
\hline \multicolumn{2}{c|}{ 計 } & 98 \\
\hline
\end{tabular}

表 2

投与方法

\begin{tabular}{c|cc}
\hline 化学療法 & $\begin{array}{l}\text { F } \\
\text { M F }\end{array}$ & $\begin{array}{c}\text { 群 } \\
\text { 群 }\end{array}$ \\
\hline 免疫癔法 & O & 群 \\
\hline $\begin{array}{c}\text { 化学療法 } \\
+\end{array}$ & FO 群 \\
免疫療法 & M F O群 \\
\hline
\end{tabular}

F : 5 Fu D.S or FT -207

$\mathrm{M}: \mathrm{MMC}$

$\mathrm{O}: \mathrm{OK}-432$

MMC $2 \mathrm{mg} 3 /$ 週 静注

$5 \mathrm{Fu} \mathrm{D.S} 200 \mathrm{mg}$ or FT-207 $600 \mathrm{mg}$ 連日経口投与

OK-432筋注： $0.2 \mathrm{KE} 3$ 日間 $0.5 \mathrm{KE} 3$

日間 $1 \mathrm{KE} 3$ 日間以後 $2 \mathrm{KE}$ を維持量とする

一以上各種組合せ 5 週間を 1 クールとする一

投与薬剤は，表 2 に示す如く，化学療法 として $5 \mathrm{Fu}$ dry syrop $200 \mathrm{mg}$ 或は FT-207 600mg を連日経口投 与, M.M.C 2mg を週 3 回静脈内投与, 免疫療法として OK-432を筋肉内投与，すなわち $0.2 \mathrm{KE}$ を 3 日間， 0.5 $\mathrm{KE}$ を 3 日間，I KE を 3 日間と漸増し，以後 $2 \mathrm{KE}$ を 稚持量として連日投与した。これらの薬剂を各種組合 せ，化学療法としてF群及び MF 群，免疫療法として 0 群, 免疫化学療法として FO 群及び MFO 群の各群 に分け 5 週間を1クールとして，施行した．全ての症 例は 1 クール投与完了症例である. 投与時期は術後生体 の内部環境の改善がみられる術後約 2 週間を目やすとし て投与開始したが，臨床症状及び臨床検查所見の状態に よって投与時期は前後した. 化学療法で問題となる副作 用については，末梢白血球数 $3 \times 10^{3} / \mathrm{mm}^{3}$ 以下，血小板 数 $\mathrm{I} \times 10^{5} / \mathrm{mm}^{3}$ 以下, トランスアミナ一ゼ 100 単位以 
上，強度の食欲不振，覀心呕吐，全身倦总感，長期に渡 る38. $0^{\circ} \mathrm{C}$ 以上の発熱などのいずれか出現した時点で菜剤 投与は中止した。

\section{第 3 節 使用郕料}

第 1 項 末梢血液

末梢血夜は，患者前腕よりへパリン加注射器にてリン 球分離用静脈血 2 3ml と非へパリン加注射器にてへ モグラム用静脈血 $2 \mathrm{ml}$ を採血し検索に用いた。

第 2 項 リンバ球識別キット

リンパ球 Subpopulationの検索は，ヒトリンパ球 T細 胞 B 細胞微量測定用キット JIMCO T-Iを使用した。

第3 項 遟延型皮虚反応用抗原

遅延型皮店反応の検索は，一般診断精製ツベルクリン (purified protein derivative of tuberculin PPD) 及び Wellcome 社製 (purified phytohemagglutinin PHA) 抗原として行った。

\section{第 4 節 検索時期}

$\mathrm{T}$ 細胞，荤延型皮唐反応及びへモグラムの検索時期 は，クール開始前日を施行前の值とし，1クール終了後 経時的に検索した結果，クール終了1週間後の值が妥当 と考え施行後の值とした。

\section{第 5 節 $\mathbf{T}$ 細胞 B 細胞の讙別法}

$\mathrm{T}$ 細胞 B 細胞の識別は JIMCO 測定法にのっとり以 下の項目の如く行った。

\section{第 1 項 リンパ球の分離}

末梢血液からのリンパ球分灕は，比重遠心法にて行っ た. すなわち， 一パリン加末梢血液 $2 \sim 3 \mathrm{ml} \mathrm{K1/15} \mathrm{M.}$ phosphate Bufferd salin (PBS) pH7.5を等量加元, 倍数 希釈検体を比重1.077のリンパ球分離試薬 Sodium Metrizoate Ficoll (SMF) 混液 $3 \mathrm{ml}$ 上飞静かに重層し, $400 \times \mathrm{g}$ にて 30分間室温にて遠心する． 比重遠心に上 り，赤血球及び顆粒球は最下層に沈殹 し，血小板及 び血浆成分は上層に浮遊，その中間にリン八球層を得 る.この中間層のリンパ球分画のみを別の試験管に採集 乙，さらに高純度のリンバ球を得る為に充分量の $1 / 15$ M.PBS を加え混和し， $240 \times \mathrm{g}$ にて10分間室温にて遠心 しリンパ球を最下層に沈濩させ一部の血小板及び血浆成 分などを浮遊させ排除した。さらに試験管底に附着した リンパ球ペレットをミキシングして分離, 再度充分量の PBS を加え $160 \times g$ にて10分間室温にて遠心しリンパ球 洗浄をを行い上澄液を除去した.ささらにすう 1 回洗浄を 行い合計 3 回のリンパ球洗浄にて高純度のリンパ球を得 た.
第 2 項 リンパ球数の調整

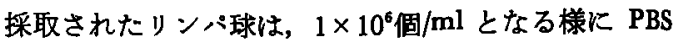
にて調整した。

第 3 項 補体感作ヒッジ赤血球 (EAC) の 洗浄 EAC は溶血を起こしやすく，溶血赤血球を除去する為に洗浄 を必要とする．すなわち，EAC 夜を小試験管倿し充 分量の PBS を加光， 約 $800 \times \mathrm{g}$ にて10分間室温にて遠 心し EAC を沈没，上澄の不純物を除去し PBS $1 \mathrm{ml}$ に 再浮遊させ $\mathrm{EAC}$ 液として使用した。

第 4 項 リンパ球のマイクロテストプレートへの滴下 $1 \times 10^{6}$ 個 $/ \mathrm{ml}$ 亿調整したリンハ球浮遊液を $50 \mu 1$ 用マイ クロシリリンジにて $1 \mu 1$ ずつ $\mathrm{T}$ 細胞判定用， B 細胞判定 用，ペルオキシダーゼ判定用の 3 枚のマイクロテストフ レート各孔に滴下附着させる.これら3枚のプレートは 蓋をし15分間室温にて放置しリンハ球を孔内に安定させ た

第 5 項 プレートの PLL ブロック

15分間放置した 3 枚のマイクロテストプレートの各孔 飞午胎児血清 Fetal Calf Serum (FCS) を T 細胞 B 細胞 判定用プレート孔には $500 \mu 1$ マイクロシリンジにて $10 \mu 1$ ずつ，ペルオキシダーゼ反応用プレート孔にはロゼット 形成不必要なため $0.5 \mu 1$ と少量静かに加え， 30分間室温 にて放置した. この様に FCSを添加することにょりフ レート孔表面の Poly-L-Lysine (PLL) をブロックし以 後の反応をスムーズにした。

第 6 項 プレート孔の洗浄

PLL ブロックを終えたマイクロテストプレート各孔 の FCS は，補体結合反応によるB 細胞の口ぜット形成 を阻害するなめ FCS の排除が必要となる.すなわち， B 細胞用プレート各孔の FCS を毛細管現象を利用して トランペット管にて除去し，各孔に PBS を盛り上げた 後，プレートを静かに反転させトランベット管にてPBS と伴に残存 FCS を排除する. この操作を 3 回くり返 L，できる限り FCS を除去する，T細胞の口ゼット形 成は FCSに阻害されない為，洗浄は不要であり FCS をトランペット管にて除去するだけで次操作を行った。

第 7 項 リンパ球とヒッジ赤血球及び補体感作ヒッシ 赤血球との反応

ヒッジ赤血球（E）及び補体感作ヒッジ赤血球(EAC) をそれぞれの条件下でりンパ球と反応させ， $\mathrm{E}$ 口ぜッ ト， EAC ロゼットを形成させた，すなわち， T細胞用 プレート各孔に E 液を， B 細胞用プレート各孔に EAC 液を各々 $500 \mu 1$ マイクロシリンジにて $10 \mu 1$ つつリンハ 


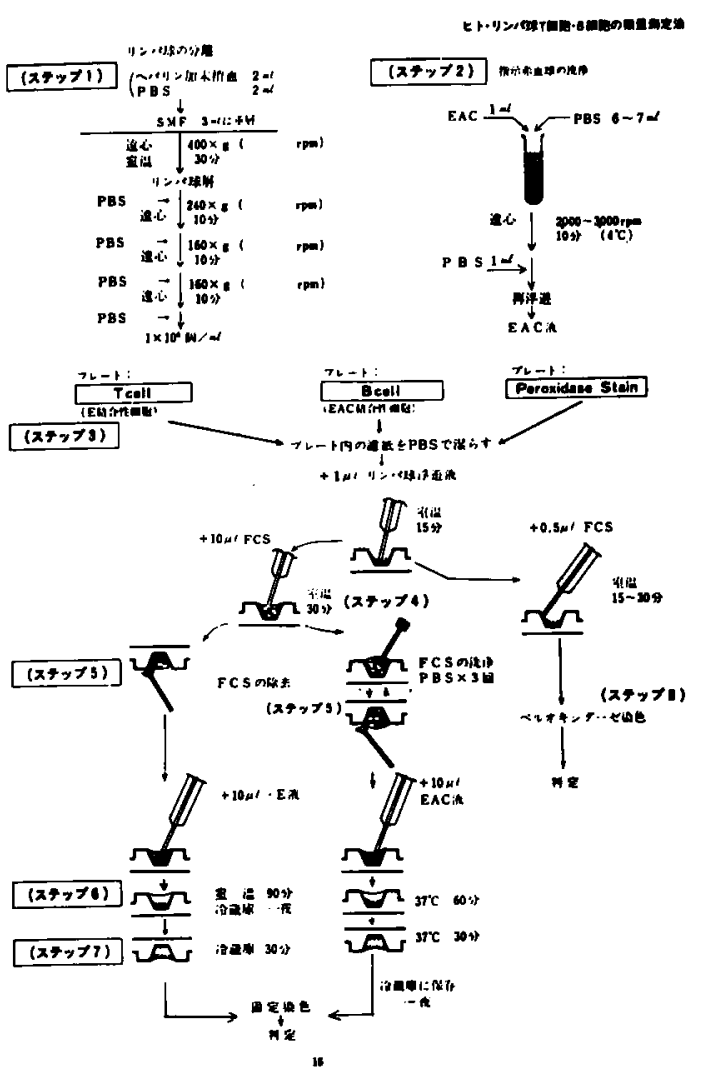

図 1

球浮遊液に滴下した，反応を鋭敏に行わせるために $\mathrm{T}$ 細

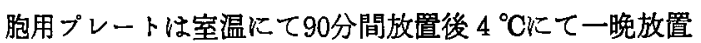
し装朝30分間倒置し反応を完了させた． B 細胞用プレー トは $37^{\circ} \mathrm{C}$ 恒常保温器内で 60 分間正圆の状態で放置後30分 間倒置にて反応を完了させた。

第 8 項 ペルオキシダーゼ反応及び染色

FCS を加え室温にて放置していたペルオキシダーゼ 反応用プレートは，ドライヤーにて乾嬠させペルオキシ ダーゼ溶液をパスッールピペットを用いて各孔にこぼれ ない程度に加光30～60秒間反応させ，さらに各孔に蒸留 水を加えてペルオキシダーゼ溶液を希积し 4 分間放置す る. その後プレートを水洗し，10倍希釈 BCB 色素配合 タルタールアルデヒド溶液を滴下染色し, そのままの状 態にてプレートを倒直し400倍率で検鏡した.

第 9 項 $\mathrm{E}$ ロゼット EAC ロゼットの固定染色

反応完了プレートを PBS を淽した適当な容器内に垂 直に保持したまま浸してゆき約15分間静置し，各孔表面 の余分な赤血球浮遊液を除去した。この際ロぜットは填
れやすいので PBS が対流を起さないように注意した。 静置後プレートを静かに引き上げ，倒置のままやや傾斜 させ余分の PBSを除去し, BCB 色素配合グルタールフ ルデヒド溶液をパスッールピペットにて静かにプレート 各孔に加え，固定染色を行った。

第10項 ペルオキシダーゼ反応及びャゼット判定法

ペルオキシダーゼ陽性細胞には黄褐色に染色された顆 粒が認められ，1 孔100個の有核細胞を算出し，合計 5 孔の陽性細胞の百分率を求めた． Eロゼット及び EAC ロゼット形成の判定は, 光学顕微鏡下400倍にて行った. 通常 4 個以上の E及び EAC の附着した有核細胞をロゼ ット形成細胞とし，1 孔約100個の有核細胞を算出し， 合計 5 孔の口ゼット形成細胞の百分率を求めた。 これら $\mathrm{E}$ ロぜット，EAC ロゼット及びペルオキシダーゼ陽性 細胞の各百分率から， $\mathrm{T}$ 細胞， $\mathrm{B}$ 細胞の百分率を算出し た. 教室での $\mathrm{T}$ 細胞及び B 細胞の正常值は，健康人 30 検 体より検索し得た結果から， T細胞 $65 \pm 4 \% ， B$ 細胞 35 $\pm 6 \%$ とし，以下の検査結果の対照とした.

\section{第 6 節 遅延型皮官反応の方法及びその判定法}

荤延型皮屑反応は，図2に示す如く，患者両側前腕に PPD $0.05 \mu \mathrm{g} / 0.1 \mathrm{ml}$, PHA $5 \mu \mathrm{g} / 0.1 \mathrm{ml}$ を抗原として $\mathrm{lmI}$ 用テルモディスポーザブルシリンジを用いて皮内接 種した. 判定は，PPD 反応は48時間後の発躯紅斑平均 径 $10 \mathrm{~mm}$ 以上を陽性，PHA 反応は24時間後の 発赤紅斑 平均径 $20 \mathrm{~mm}$ 以上を陽性とした。

\section{第 III 章 検查結果}

検査結果は，個々の患者に於ける治療前後の值の変動 をみたもので，予後判定は，非切除例及び再発例の予後 を考虑にいれ，クール終了後 3 ケ月目の時点で行った。

第 1 節 $\mathbf{F}$ 群施行前後に於ける $\mathbf{T}$ 細胞及び遲延型皮在 反応の変化 (図 3 )

$\mathrm{T}$ 細胞比に於いては，その平均值は投与前 $62.7 \%$ ，投 与後 $59.7 \%$, 又個々の変動をみると 19例中14例 (73.7 \%)に低下を認めた． $\mathrm{T}$ 細胞絶対数に於いては，その平均 值は投与前 1,192 個 $/ \mathrm{ml}$, 投与後 1,065 個 $/ \mathrm{ml}$, 又個々の変 動では19例中12例 (63.1\%) に低下を認めた， T 細胞比 及び $\mathrm{T}$ 細胞絶対数ともに投与後值は低下の㑯向を示し

PPD : $0.05 \mathrm{ug} / 0.1 \mathrm{ml}$ 接種 48 時間後判定 PHA : $5 \mathrm{ug} / 0.1 \mathrm{ml}$ 接種 24 時間後判定

判定基準

PPD 反応：平均径 10 $\mathrm{mm}$ 以上を陽性

PHA 反応：平均往 20mm 以上を陽性

园2 皮后反店の各種抗原と判定 

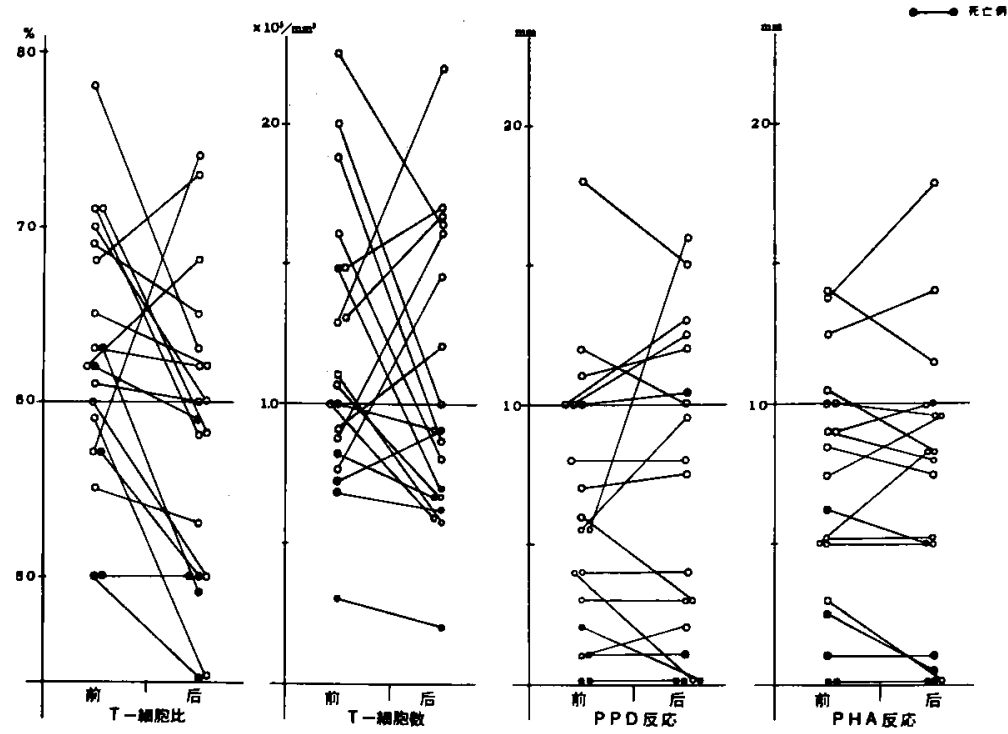

図 3 F 群施行前後に於ける T-細胞及び逮延型皮嘃反応の変化
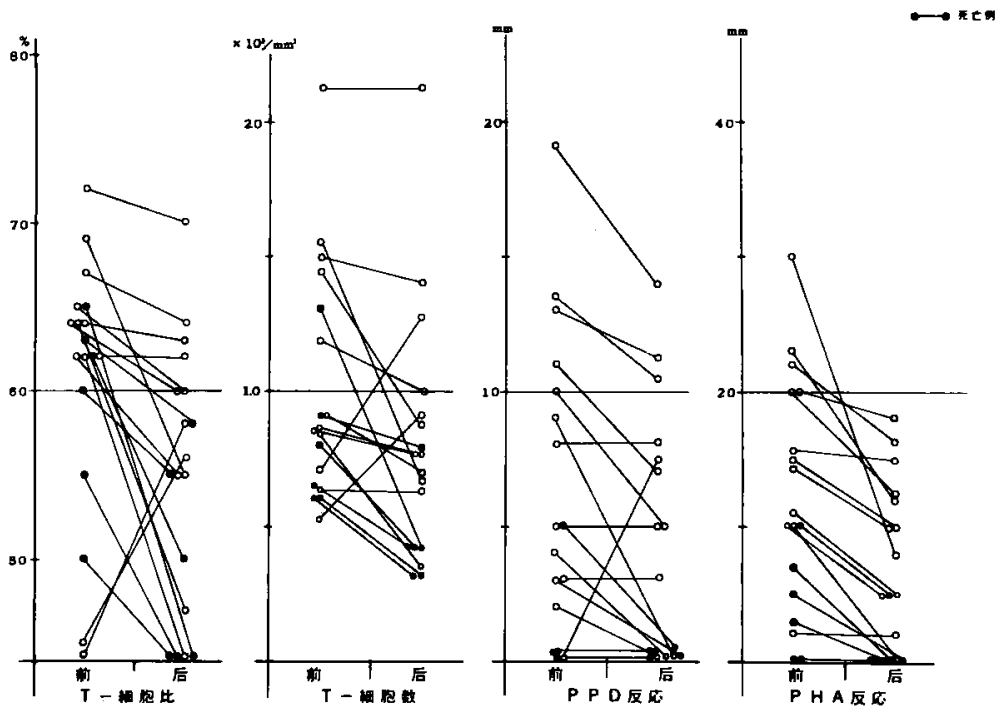

図 $4 \mathrm{MF}$ 群施行前後における T-細胞および㜊延型皮后反応の変化

た.PPD 反応に於いては，ての平均值は投与前 $6.2 \mathrm{~mm}$, 投与後 $6.6 \mathrm{~mm}$, 個々の変動では19例中 5 例 $(26.3 \%)$ K 反応の低下，19例中 8 中 $(42.1 \%)$ に反応の上昇がみら

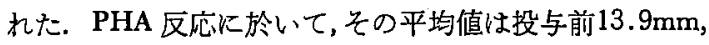
投与後 $13.8 \mathrm{~mm}$ ，個々の変動では19例中 7 例 $(36.8 \%)$ に反応の低下，19例中 5 例 (26.3\%) に反応の上昇がみ られた。
第 2 節 $M F$ 群施行前後に於ける $T$ 細胞及び荤延型皮 虐反态の変化 (図 4)

多剂に上る化学療法 MF 群に於いて T 細胞比の平均 值は投与前 $60.7 \%$ ，投与後 $56.2 \%$, 又個々の变動では 18 例中15例 $(83.3 \%)$ に低下を認めた. T細胞絶対数に於 いては，その平均値は投与前971個/ $/ \mathrm{ml}$, 投与後874個/ml, 個々の変動では18例中14例（77.8\%）に低下を認めた. 
PPD 反応に於いては，その平均値は投与前 $5.8 \mathrm{~mm}$ ，投 与後 $4.0 \mathrm{~mm}$, 個々の変動では18例中10例 $(55.6 \%)$ に反 応の低下を認め，反応上昇例は 1 例のみであったＰHA 反応に於いては，その平均值は投与前 $12.2 \mathrm{~mm}$ ，投与後 $6.8 \mathrm{~mm}$, と可成の低下を認め, 個々の变動では18例中15 例 $(83.3 \%)$ に反応の低下を認め，反応上昇例は皆無で あった。
第 3 節 切除別にみた化学捇法施行前後に於けるT細 胞及び幄延型皮成反応の变化（图 5, 図6）

F及び MF による化学療法施行前後に於けるT細胞 及び遅延型皮㕅反応の変化を切除別にみると，治瘾切除 例では， $\mathrm{T}$ 細胞比の平均値は投与前 $65.2 \%$ ，投与後 63.1 $\%$ ，個々の変動をみると，14例中 9 例 $(64.3 \%)$ に低下 を認めるが正常範囲での変動であった. T細胞絶対数で

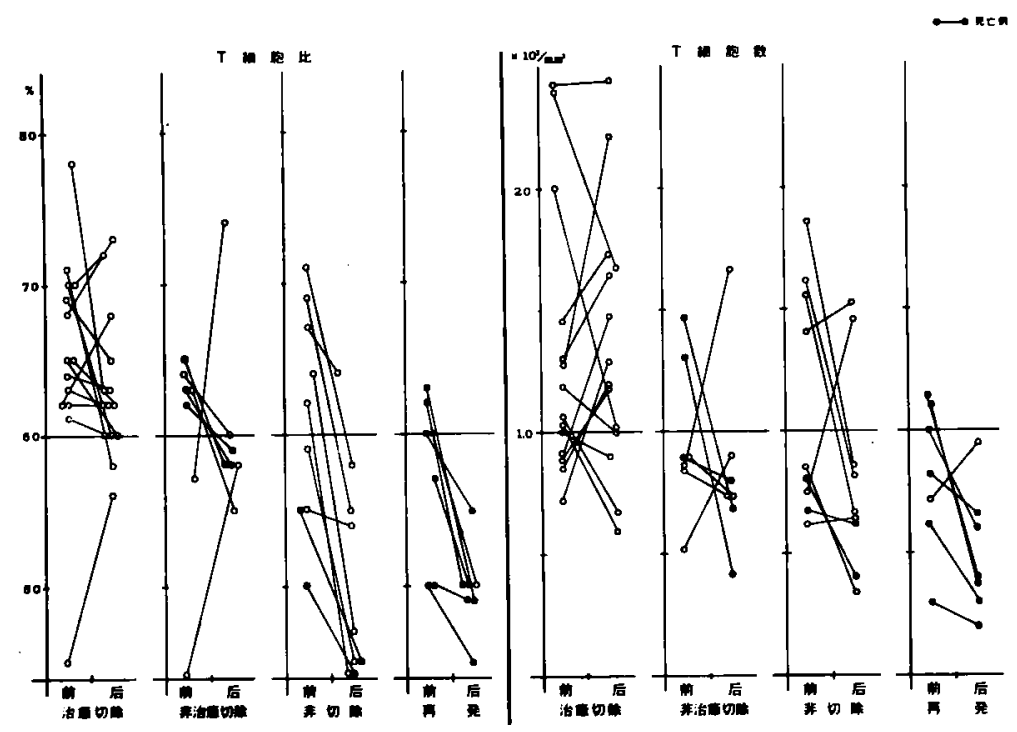

図 5 化学浾法施行前後における $\mathbf{T}$-細胞の变化

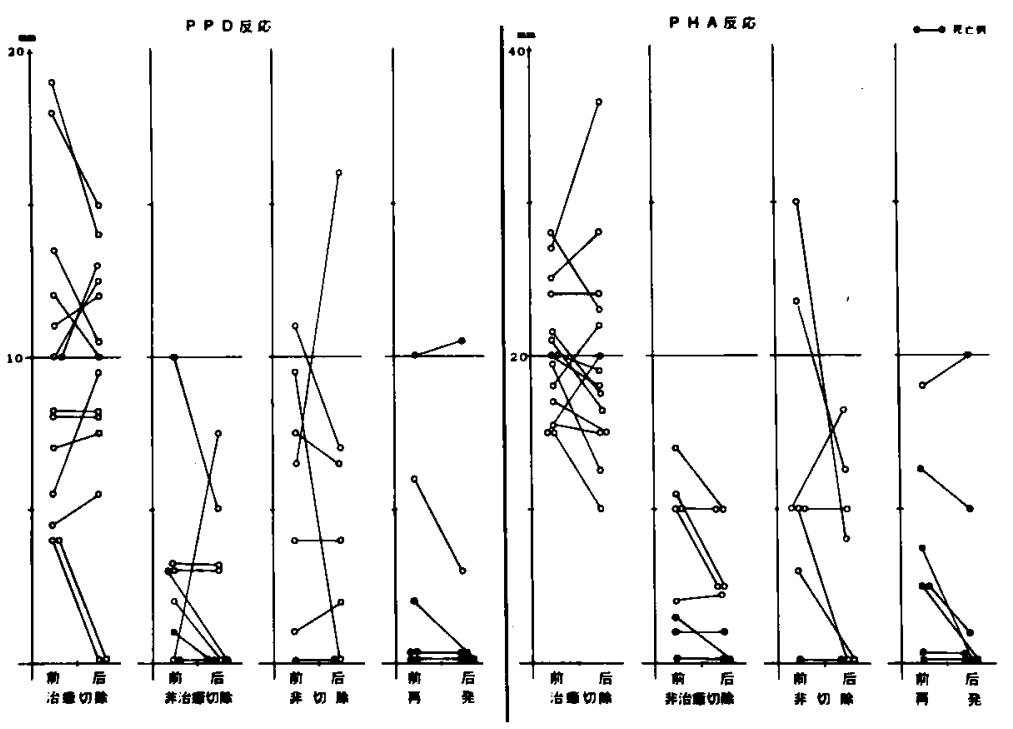

図6 化学庶法施行前後に於ける幄延型皮尚反応の変化 
は，その平均値は投与前 1,330 個 $/ \mathrm{ml}$, 投与後 1,347 個 $/ \mathrm{ml}$ と軽度增加を認め, 又個々の変動に於いてむ14例中 7 例 （50.0\%）に增加を認めた．PPD 反応では，その平均值 は投与前 $9.6 \mathrm{~mm}$, 投与後 $8.9 \mathrm{~mm}$. 個々の変動では 14 例中 6例 $(42.9 \%)$ に上昇を認めた. PHA 反応では，その 平均值は投与前 $20.2 \mathrm{~mm}$. 投与後 $18.9 \mathrm{~mm}$ と軽度低下， 個々の変動では14例中 9 例 $(64.3 \%)$ 飞低下を認めるが 軽度の変化が多かった．非治癋切除例では， T細胞比の 平均值は投与前 $59.6 \%$ ，投与後 $58.8 \%$ と平均値には有意 な変化は得られないが，個々の変動をみると 7 例中 5 例 （71.4\%）に低下を認めた。， T 細胞絶対数をみると，そ の平均值は投与前 973 個 $/ \mathrm{ml}$ ，投与後 833 個 $/ \mathrm{ml}$ と低下を 示し，個々の变動に於いても 7 例中 5 例 $(71.4 \%)$ は投 与後の低下を認めた．PPD 反応では，その平均值は投 与前 $3.1 \mathrm{~mm}$, 投与後 $1.6 \mathrm{~mm}$, 又個々の変動をみても正 常範围まで増強しているのは1例のみで，投与後反応は 低下を示した，PHA 反応では，その平均值は投与前 $7.1 \mathrm{~mm}$, 投与後 $4.6 \mathrm{~mm}$ と低下し, 個々の变動に於いて む1例の軽度反応増強をみたのみであった．非切除例で は， $\mathrm{T}$ 細胞比の平均值は投与前 $61.3 \%$, 投与後 $49.7 \%$ と 著明な低下を示し，個々の変動に於いても全例低下を示 した， T細胞絶対数をみても，平均值は投与前1058個/ $\mathrm{ml}$ ，投与後828個/ $\mathrm{ml}$ 之低下し，個々の変化泛於いても 9 例中 6 例 $(66.7 \%)$ に低下を認めた．PPD 反応で は，その平均値は投与前 $5.4 \mathrm{~mm}$, 投与後 $5.3 \mathrm{~mm}$, 個々の
変動では反広增強例もみられ有意な差は得られなかっ た. PHA 反応では，その平均值は投与前 $11.5 \mathrm{~mm}$ ，投 与後 $6.3 \mathrm{~mm}$ と反応低下を認め, 個々の変動でも強度に 反応低下例か 7 例中 4 例 $(57.1 \%)$ に認めた. 再発例て は, $\mathrm{T}$ 細胞比の平均値は投与前 $57.4 \%$, 投与後 $49.8 \%$ と 著明に低下し，予後的な面からみても生存例は 1 例のみ であった， T細胞絶対数に於いてる，その平均值は投与 前668個 $/ \mathrm{ml}$ 投与後 492 個 $/ \mathrm{ml}$, 又個々の変動に於いても 生存例 1 例のみ投与後の細胞数増加を認めた。 PPD 反 応では，投与前平均值は $2.6 \mathrm{~mm}$ と反応弱く，投与後も $1.9 \mathrm{~mm}$ と弱い反応であった．個々の変動に於いても無 反応例が 7 例中 4 例 $(57.1 \%)$ に認めた. PHA 反応子 PPD 反応之同様に反応は弱く，その平均值は投与前 6.9 $\mathrm{mm}$, 投与後 $4.4 \mathrm{~mm}$, 個々の変動に於いても生存例 1 例 のみ投与後反応が軽度增強したのみだった。

\section{第 4 節 0 群施行前後に於ける $\mathrm{T}$ 細胞及び㜊延型皮成}

\section{反店の变化 (図 7 )}

$\mathrm{T}$ 細胞比の平均值は，投与前 $61.0 \%$ ，投与後 $61.3 \%$ と 平均値に於いては変動はみられなかったが，個々の変動 をみると，死亡例は全例とも値は不変もしくは低下して おり，生存例では13例中 9 例 $(69.2 \%)$ に投与後の上早 を認めた．T細細絶対数に於いては，その平均值は投与 前 1,217 個 $/ \mathrm{ml}$ ，投与後 1,513 個 $/ \mathrm{ml}$, 又個々の变動に於い て 19例中16例 (84.2\%) は投与後 T 細胞数增加を認め た. PPD 反応に於いては，その平均值は投与前 $5.9 \mathrm{~mm}$
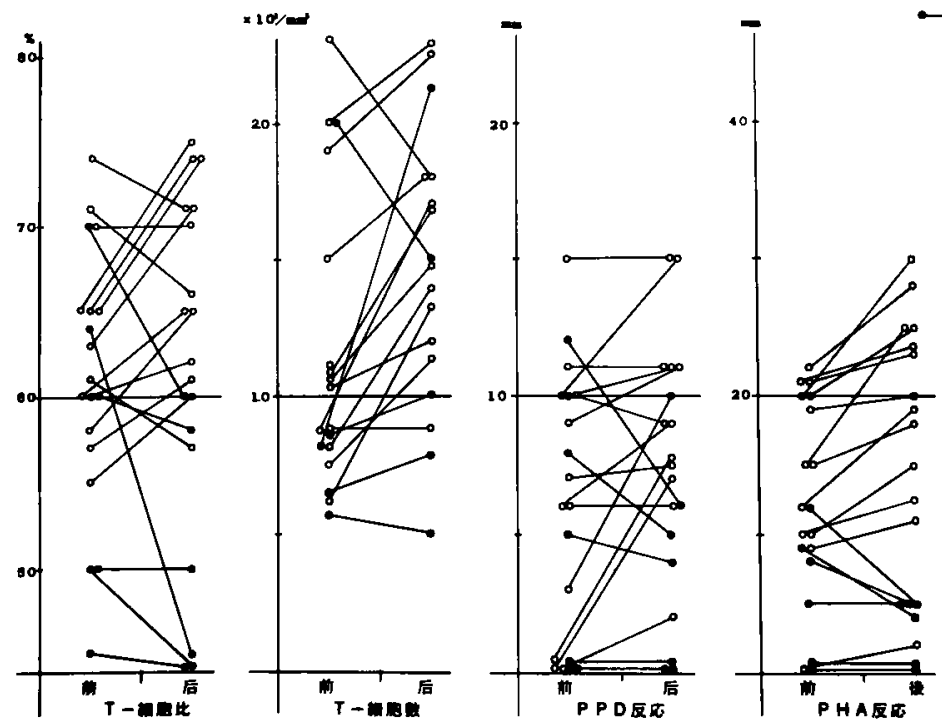

図 7 O 群施行前後に於ける T-細胞および迤延型皮成反応の変化 
投与後 $7.2 \mathrm{~mm}$ ，個々の変動では，生存例では 1 例のみ投 与後の反応低下を認めた. 死亡例では，投与前無反応症 例む多く，全例とす反応は不変から低下を示した. PHA 反応に於いては，その平均值は投与前 $13.2 \mathrm{~mm}$ ，投与後 $14.3 \mathrm{~mm}$ であったが，個の変動では，生存例全例とも投
与後の反応は増强した。すなわち，生存例に於いては， T 紐胞及び遅延型皮庙反応とも投与後の值は上舁傾向に あった。

第 5 節 切除別にみた兔疫暴法施行前後に於ける 胞及び幄延型皮成反応の変化（図 8, 図9）

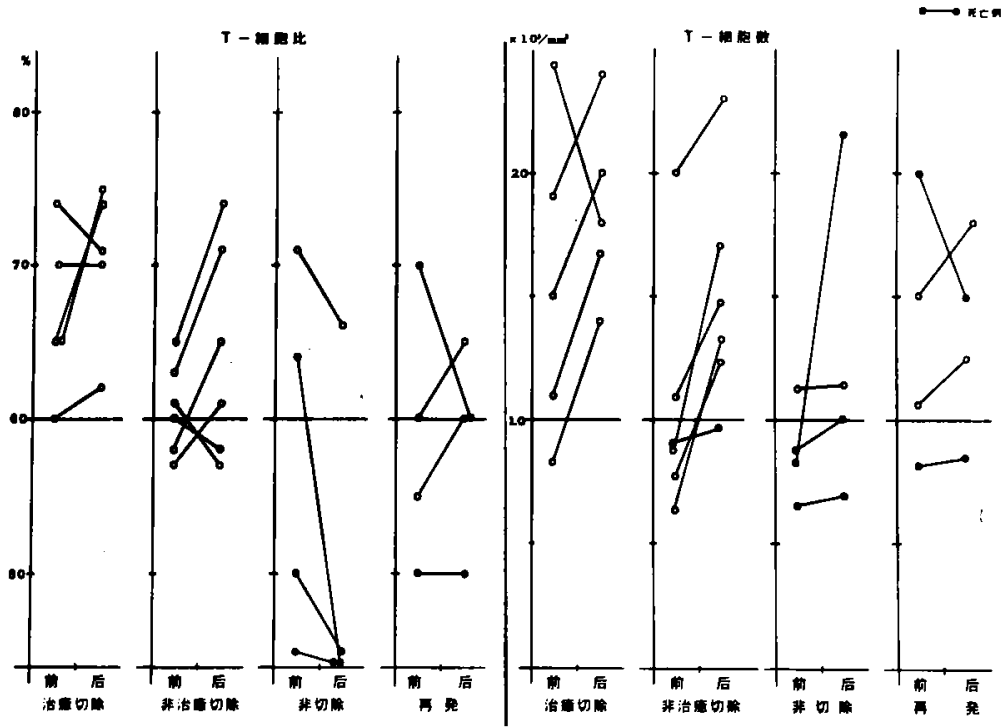

図8 免疫虔法施行前後に於ける T-細胞の変化
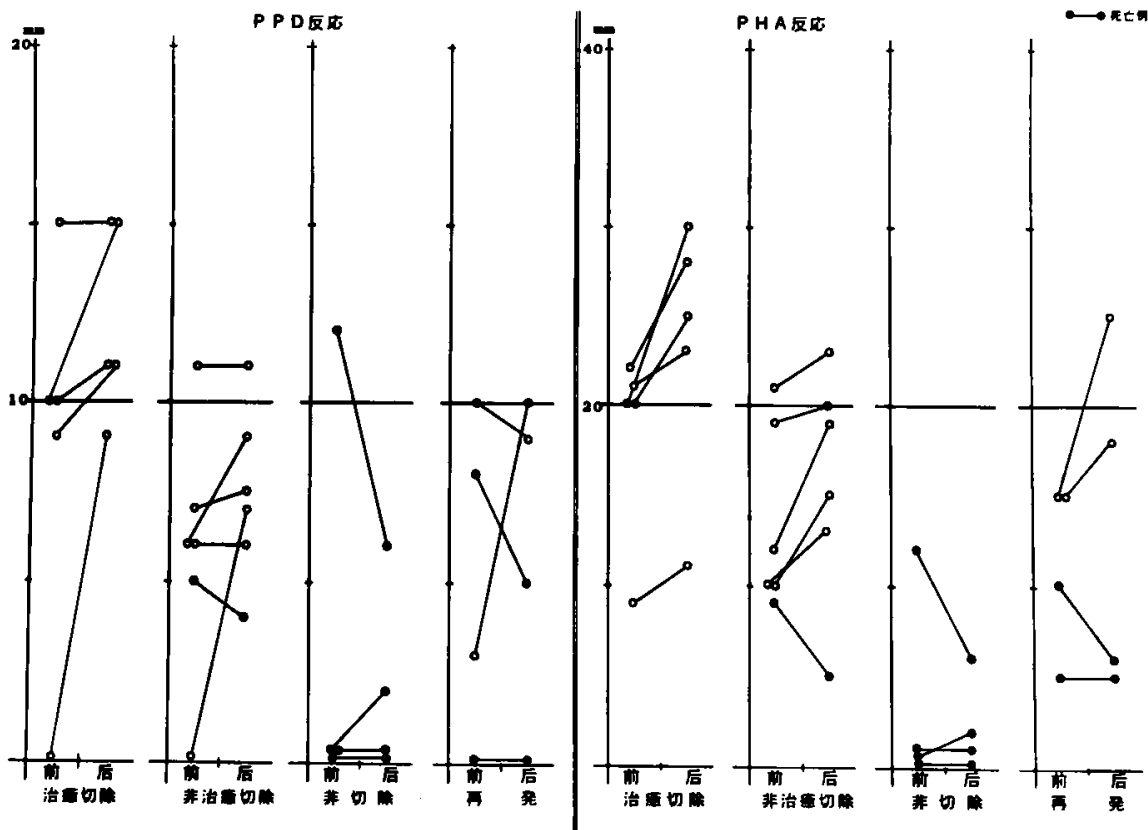

図 9 免疫挂法施行前後に於ける幄延型皮虚反応の変化 
治㾉切除例では， $\mathrm{T}$ 細胞比の平均值は投与前 $66.8 \%$, 投与後70.4\%と上昇，又個々の变動をみても，1例のみ 正常範囲での低下を示した． $\mathrm{T}$ 細胞絶対数では，その平 均値は投与前 1,594 個 $/ \mathrm{ml}$ ，投与後 1,857 個 $/ \mathrm{ml}$ と投与後 $\mathrm{T}$ 細胞数は增加した．個々の变動に於いても5 例中 4 例 （80.0\%）飞增加を認めたＰPD 反応では，その平均值 は投与前 $8.8 \mathrm{~mm}$, 投与後 $12.2 \mathrm{~mm}$, 又個々の変動に於い ても全例反応は增強した．PHA 反応に於いても，PPD 反応同様全例反応の增強を認め，平均值でも投与前 18.4 $\mathrm{mm}$, 投与後 $23.4 \mathrm{~mm}$ と増強している. 非治疮切除例で は， $\mathrm{T}$ 細胞比の平均值は投与前 $60.7 \%$, 投与後 $64.3 \%$, 個々の変動に於いても6 例中 4 例 $(66.7 \%)$ に投与後値 の上昇を認めた， $\mathrm{T}$ 細胞絶対数です，その平均值は投与 前1042個/ $/ \mathrm{ml}$ ，投与後1,514個 $/ \mathrm{ml}$ 々増加し，個々の変動 でる，投与後全例增加を認めた．PPD 反応では，その平 均值は投与前 $5.8 \mathrm{~mm}$, 投与後 $7.4 \mathrm{~mm}$ 亡反応は増強 し, 個々の変動に於いても，死亡例を除いて反応は投与後不 変から增強を示した.PHA 反応に於いても同様の傾向

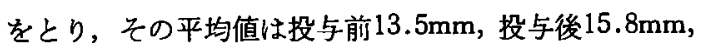
であった。非切除例では， T細胞比の平均値 は投与前 $56.5 \%$ ，投与後 $48.0 \%$ と低下し，個々の変動でる全例と む低下した。しかしT細胞絶対数に於いては増加の傾向 を示し, その平均値は投与前 875 個 $/ \mathrm{ml}$, 投与後 1,252 個/ $\mathrm{ml}$ であった．PPD 反応では無反応症例が多く，その平 均值は投与前 $3.0 \mathrm{~mm}$, 投与後 $2.0 \mathrm{~mm}$, であり, 又 $\mathrm{PHA}$ 反応に於いて子同様の傾向で，その平均値は投与前 3.0 $\mathrm{mm}$, 投与後1.8mm であった. なお，これらの症例は全 例死亡例であった。再発例では, $\mathrm{T}$ 細胞比の平均値は投 与前 $58.8 \%$, 投与後 $58.8 \%$ と不変であったが, 生存例で は投与後值は上昇している. T細胞絶対数に於いても， その平均值は投与前 $1,350 / \mathrm{ml}$. 投与後 $1,342 / \mathrm{ml}$ と不変 であるが，生存例での投与後値は增加している. PPD 反応では，その平均值は投与前 $5.3 \mathrm{~mm}$ ，投与後 $6.0 \mathrm{~mm}$, PHA 反応で，その平均值は投与前 $11.3 \mathrm{~mm}$, 投与後 $13.5 \mathrm{~mm}$ であった。

第 6 節 FO 群施行前後に於ける $\mathbf{T}$ 細胞及び迤延型皮 虚反応の変化（図10）

$\mathrm{T}$ 細胞比に於いては，その平均值は投与前 $59.5 \%$ ，投 与後 $63.5 \%$ 上上昇し, 個及の変動に於いてむ, 死亡例を 除き12例中 9 例 $(75.0 \%)$ に投与後値の上昇を認めた. $\mathrm{T}$ 細胞絶対数に於いては，その平均值は投与前 802 個 $/ \mathrm{ml}$ 投与後936個 $/ \mathrm{ml}$ と增加し, 個々の変動に於いて子生存 例12例中10例(83.3\%)に投与後の增加を認めた. PPD 反 応では，その平均値は投与前 $5.4 \mathrm{~mm}$, 投与後 $8.3 \mathrm{~mm}$ と 反応増強がみられ, 個ヶの変動では, 生存例12例中 9 例 （75.0\%）に投与後反成増強が認められた. PHA 反応
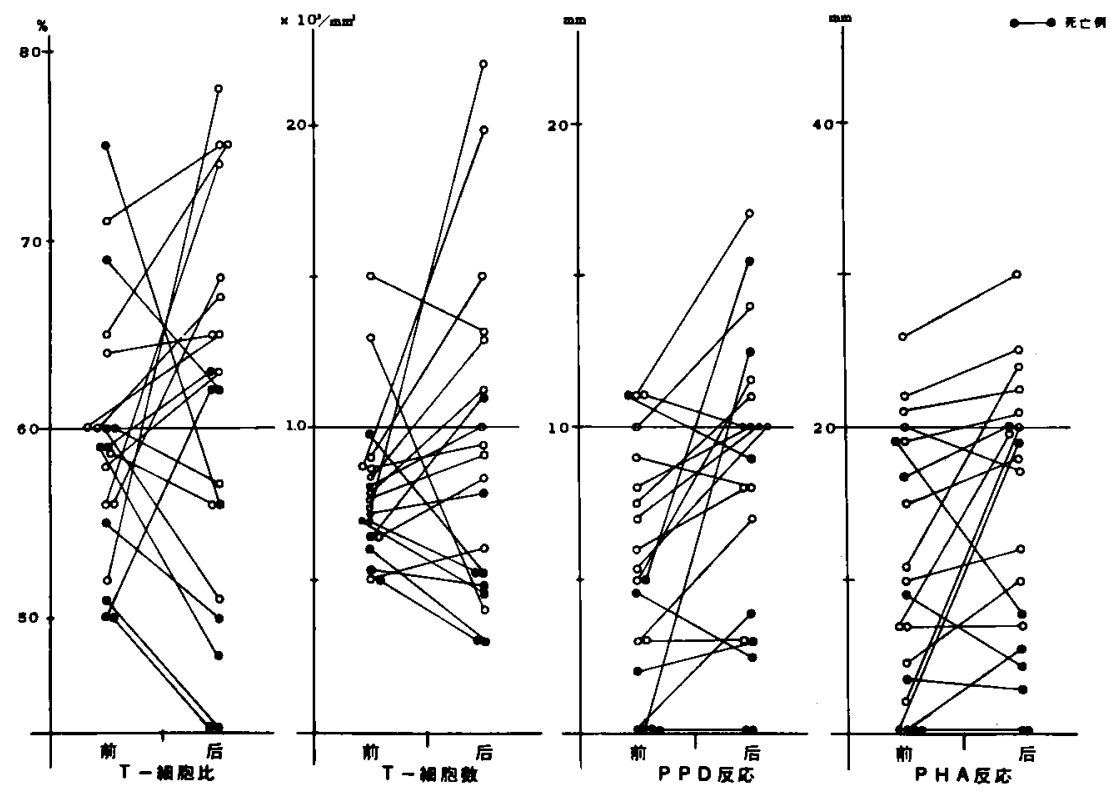

図10 FO 群施行前嵝に於ける T-細胞および幄延型皮虐反応の変化 

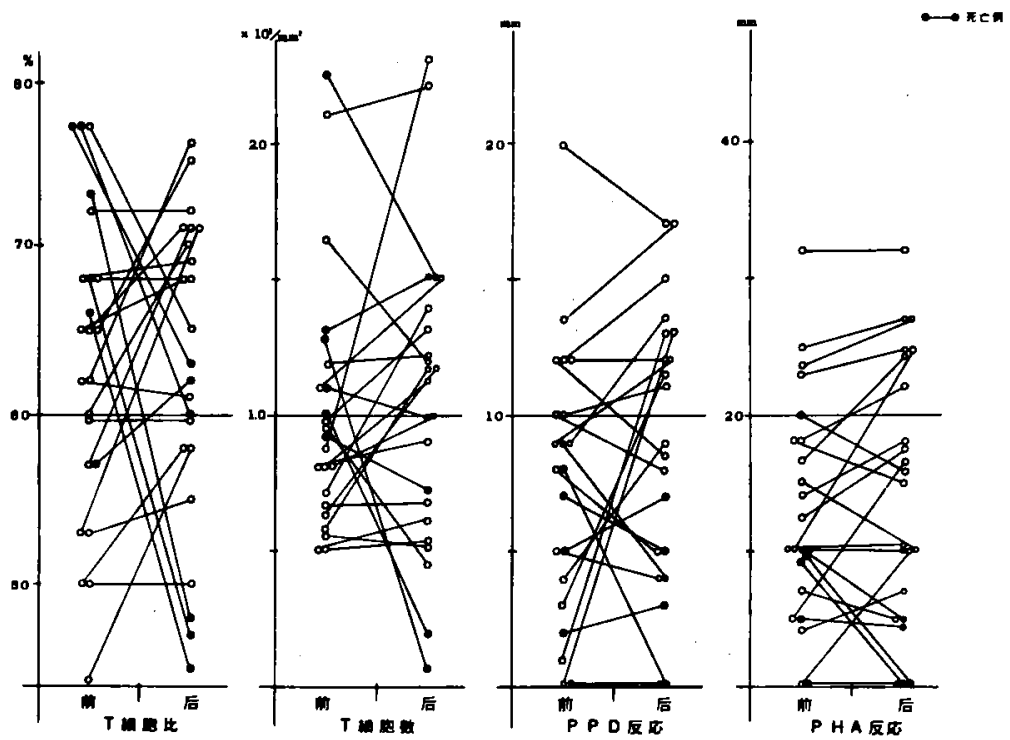

図11 MFO 群施行前後におけるT細胞および迤延型皮成反応の变化

むPPD 反応と同様な変化を示し，その平均値は投与前 $10.6 \mathrm{~mm}$ が投与後 $14.3 \mathrm{~mm}$ 之反応增強がみられ，個々 の変動に於いても生存例12例中 10例（83.3\%）に反応增 強が認められた。

第 7 節 MFO 群施行前後に於ける $\mathbf{T}$ 細胞及び遅延型 皮虚反度の变化（図11）

$\mathrm{T}$ 細胞比に於いて，その平均值は投与前 $62.9 \%$ ，投与 後 $62.6 \%$ とほぼ同様の値を示したが，投与後值の低下す る症例は息とんど死亡例で, 生存例に於いては17例中11 例(64.7\%)に投与後値の上昇がみられた. T細胞絶対数 に於いても，その平均値は投与前1059個/ml 投与後1097 個 $/ \mathrm{ml}$ とほぼ同数で，個々の变動では17例中12例（70.6 \%) に投与後の増加がみられたＰPD 反応では，その 平均值は投与前 $7.7 \mathrm{~mm}$, 投与後 $8.7 \mathrm{~mm}$ と軽度反応の増 強を認め, 個々の変動では, 生存例17例中 9 例(52.9\%) に投与後反応の增强を認めた. PHA 反応に於いても PPD 反応と同様，乙の平均値は投与前 $12.9 \mathrm{~mm}$, 投与後 $14.1 \mathrm{~mm}$ と反応の堌強がみられ，個々の変動に於いても 生存例17例中 11 例 $(64.7 \%)$ 飞投与後反応の増強を認め た.

第 8 節 切除別にみた免疫化学暴法施行前後に於ける $\mathbf{T}$ 細胞及び遲延型皮膚反応の变動（図12，図13）

治空切除例に於いては， $\mathrm{T}$ 細胞の平均值は投与前 63.0 $\%$, 投与後 $66.3 \%$ と上昇し, 個々の変動でも 1 例の低下
症例をみたのみであった， 丁細胞絶対数では，その平均 值は投与-前 945 個 $/ \mathrm{ml}$, 投与後 1,456 個 $/ \mathrm{ml}$ と増加乙, 個 々の変動に於いても低下症例は 2 例のみであった．PPD 反応では，その平均值は投与前 $7.8 \mathrm{~mm}$, 投与後 $10.5 \mathrm{~mm}$ と反応増強を認め, 又 PHA 反応に於いても同様に，そ の平均値は投与前 $17.7 \mathrm{~mm}$ ，投与後 $20.3 \mathrm{~mm}$ と反応の増 強を認めた，個々の変動では，両者とも2 例の反応減弱 をみただけであった，非治癋切除例に於いては，T細胞 比の平均值は投与前 $60.4 \%$, 投与後 $63.0 \%$ と上昇し，個 々の変動に於いては, 生存例では 7 例中 6 例 $(85.7 \%)$ に投与後值の上昇をみた． $\mathrm{T}$ 細胞絶対数に於いても，そ の平均値は投与前 1 , [36個/ml 投与後 1,209 個/ $/ \mathrm{ml}$ と増加 し，個々の変動でも生存例では全例投与後に増加を示し た. PPD 反応では，その平均値は投与前 $5.4 \mathrm{~mm}$, 投与 後 $7.9 \mathrm{~mm}$ と反応は増強し，個々の変動です 1 症例に反 応減弱をみたのみであったＰPHA 反応では，その平均 值は投与前 $12.2 \mathrm{~mm}$ ，投与後 $14.9 \mathrm{~mm}$ と反応は増強し， 個々の変動でも生存例全例に反応増強をみた．非切除例 では， $\mathrm{T}$ 細胞比の平均值は投与前 $60.5 \%$ ，投与後 $57.5 \%$ と低下し，個々の変動に於いても10例中 5 例 (50.0\%) に投与後值の低下を認めた. 又 $\mathrm{T}$ 細胞絶対数に於いて も，平均值は投与前 815 個 $/ \mathrm{ml}$, 投与後696個 $/ \mathrm{ml}$ と減少 し，個々の变動でも10例中 4 例 $(40.0 \%)$ 飞投与後の減 少を認めた. しかし遅延型皮膚反応の平均值は投与後上 


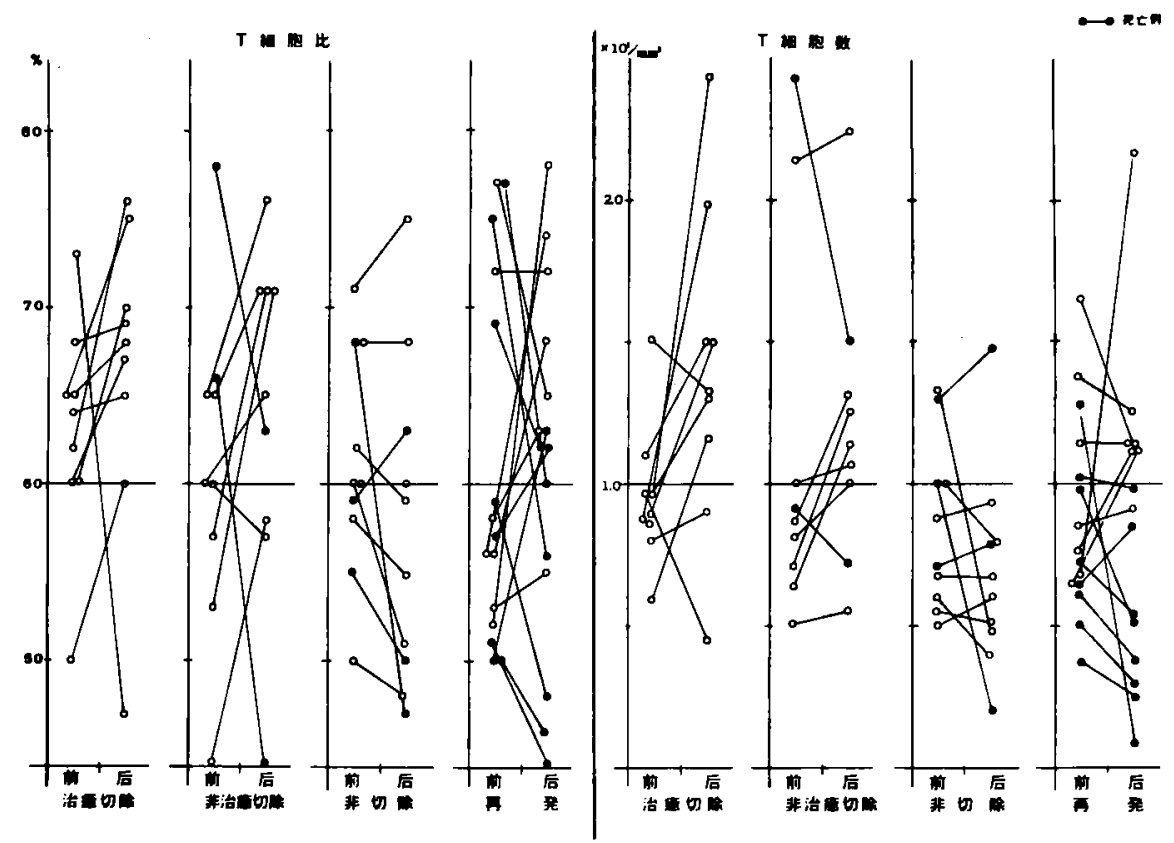

図12 兔疫化学滰法施行前後における T-細胞の変化
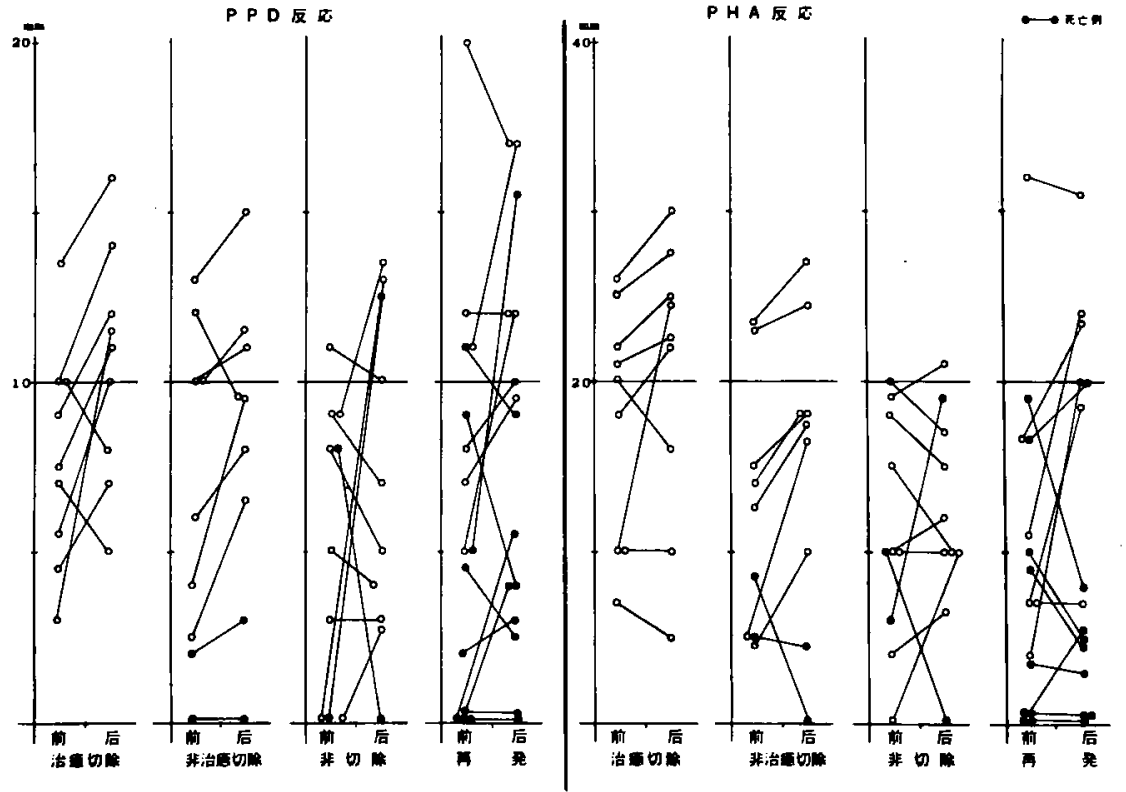

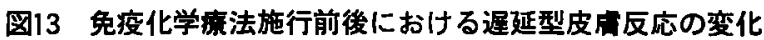

昇し，PPD 反応では，投与前 $4.8 \mathrm{~mm}$ ，投与後 $7.1 \mathrm{~mm}$ ， PHA 反応では，投与前 $9.6 \mathrm{~mm}$ ，投与後 $10.5 \mathrm{~mm}$ であっ た. 個々の変動では，両者とす10例中 4 例 $(40.0 \%) に$
反応の 減弱がみられた. 再発例に於いては，T細胞此 の平均值は投与前 $61: 3 \%$, 投与後 $60.6 \%$ 之低下し，死亡 例が多く，個々の変動に於いても14例中 6 例 $(42.9 \%)$ 
に投与後値の上昇をみたのみであった，T細胞絶対数に 於いても平均値は投与前 867 個 $/ \mathrm{ml}$ 投与後 850 個 $/ \mathrm{ml}$ 之軽 度減少し, 又個々の変動です14例中10例 $(71.4 \%)$ は投 与後减少を認めた. PPD 反応では，その平均值は投与 前 $8.0 \mathrm{~mm}$, 投与後 $8.4 \mathrm{~mm}$, PHA 反応での平均值は，投 与前 $9.5 \mathrm{~mm}$, 投与後 $11.8 \mathrm{~mm}$ で，両者とも軽度の反応增 強をみたが，個々の変動では，PPD 反応は14例中 7 例 (50.0\%),PHA 反応では14例中 6 例 $(42.9 \%)$ にしか反 応の增強はみられなかった。

\section{第IV章考案

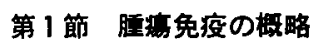

近年, 兔疫学を基礎にした癌の研究が再び脚光を浴び る様になってきた. 癌細胞は本来自己の細胞から発生し たもので，感染症の如く全くの異物が体内に侵入したも のとは本質的烘っている. しかし，Foley Edward J4) の実験、すなわち、マウスに methylcholanthrene で董 瘍を誘発し同系マウスに移植すると睡場は增殖発育す るにるかかわらず，その腫湯を摘除したマウスに腫瘍細 胞を再移植しても尰䕐の発育は拒絶された事実, さらに

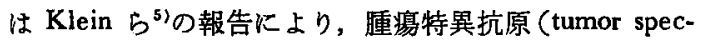
ific antigen TSA) の存在が評価され癌免疫の存在が明 らかになった. しかし癌細胞に対する免疫反応が引き起 こされるにもかかからず，多くの癌が生存し得るといら 逆説的な現象を探求することが, 又今日の癌研究の主題 であろ56)。癌特異抗原之は, 一般には同系において癌 細胞の成分が異物と認識され，それに対して同系宿主に 免疫応答が起る際, その癌細胞成分は癌特異抗原である と考えられている. 特に, 自家或は同系の癌一宿主系 の癌細胞移植拒否現象が起る場合, その免疫反応を規定 する癌抗原を癌特異移植抗原 (tumor specific transplantation antigen TSTA) と呼んでいる゙. 人癌の場合, 癌 特異抗原はまだ一般化されるに至ってないが，抗原性が あっても弱いものだと考穴られている。しかし人癌に対 する生体の免度応答の存在は, 臨床的にる支持する幾多 の事実がある11919?. 例ば，免疫不全症候群中免疫抑制療 法をらけた患者では発癌頻度が高くなっており ${ }^{10)}$, 生体 の免疫応答と発癌は動かしがたい事実である. 免疫機構 の発達した高等動物ではリンパ球を中心とする細胞性免 疫が出現した变異細胞を識別し排除して生体の恒常性を 稚持すると考えられており，この様な調節機構を Burn$\mathrm{et}^{111}$ は免疫学的監視 (immunological surveillance) とい ら概念で総括した。この概念に従えば，発癌は変異細胞 が宿主の免疫学的監視をのがれて增殖し得た場合に起る
ことになる. しかし，変異細胞が宿主の免疫学的監視を のがれる機序は解明されていない ${ }^{12)}$. 自己の細胞を母地 として発生した癌細胞に対する免疫応答は, 感染症の如 く外因性の抗原に対する免疫応答の原則に果してあては まるだろらか。癌発生母地, 組織構造, さらには複雑な 発育様式などの相異によって必ずしも同じ免疫応答はあ りえないと思われる．いずれにせよ腫湟免疫のエフェク ター機構は十分に解明されなければならない。

\section{第 2 節 睡像細胞に対する生体の応答}

前述の如く，腫場特異移植抗原の存在がある程度確立 されてきており，癌細胞に対する生体の応答は Burnet が提陧した免疫監視機構になっているといら考えが主要 であるが，な打明確でない事実も多い，しかしその機構 の主体は， T細胞とマクロファージを中心とした細胞性

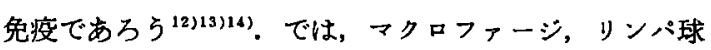
がどの様なエフェクター機構をるって癌細胞に対処する のたろらか. 現在のところ癌細胞障害を示す細胞関与 の免疫機構として次の事項が考えられている(1)15)16).

1） T細胞（cytotoxitic lymphocyte）による細胞障害,

2) 抗体之の協同作用に上る細胞障害 (antibody dependent cell-mediated cytotoxity ADCC), 3) アーミング 因子によるマクロファージの特異的細胞障害, 4) マク ロファージの活性化による非特異的細胞障害，5） Natural Killer 細胞による 細胞障害, などである. しか し,この様に癌に対する免疫応答があるにもかかわらず 癌の增殖は現実に起っている.なぜ癌細胞が宿主の免疫 監視機構から escape して增殖するのだろらか. 明確な 解答は得られないが, その理由の1つとして, 癌の抗原 性は低く，その抗原によって感作され癌細胞障害に働く ような抗体が産生されてもその量は癌拒否を起こす程充 分ではなく, 又癌細胞障害に働く細胞性抗体が宿主に誘 導されても同時にその作用を阻止するような因子（blocking factor) が産生される ${ }^{17}$. 一方, 癌細胞が産生する 毒性物質によって， $\mathrm{T}$ 細胞，マクロファージの機能低下 せしめることも認められて朔り, 癌增殖を余儀なくさせ るといった悪循環をくり返するのと考えられる.

\section{第 3 節 細胞性兔疫能の険索}

第 1 項 $\mathrm{T}$ 細胞 $\mathrm{B}$ 細胞の同定

細胞性免没の主役は, リンパ球及びマクロファージで あり, 特にリンハ球は免疫学的観点から 2 つの Population に分類されている(12)18)19)。 その1つは胸腺由来細 胞 thymus-dirived lymphocyte $\mathrm{T}$ 細胞, む5 1 つは骨 髄由来細胞 bone marrow derived lymphoeyte or bursa 
equivalent-dirived lymphocyte B 細胞である.これら 細胞の同定は，細胞表面マーカーを利用して可能であ $\eta^{19) 20)}$ ， T 細胞マーカーとして，羊赤血球との spontaneus rosette formation ( $E$ rosette) ${ }^{21)}$ ，抗胸腺血清によ る細胞障害試験 ${ }^{22)}$, HTL 抗原 (human thymuslymphoid

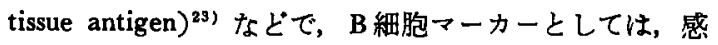
作ヒツジ赤血球に補体第 3 成分をつけた EA-Complement 細胞による rosette formation (EAC rosette) ${ }^{24)}$ 細 胞表面免疫グロブリンの存在 ${ }^{25) 26)}, \mathrm{Fc}$-receptor の存在 19201なとが知られている。しかし，T細胞と言えどす単 一の細胞集団ではなく，その機能的検索によりいくつか の異った機能的分団 (subsets) が存在することが明らか になっている，細胞障害に働く $\mathrm{T}$ 細胞（Killer $\mathrm{T}$ cell or cytotoxitic lymphocyte C L), CL 誘導にあずかるT 細胞 (amplifier T cell), 遅延型過敏症を起こすT細胞 (delayed hypersensitivity $\mathrm{T}$ cell) 抗体産生に際してB 緗胞と協同作用を行ら T細胞 (helper T cell) などであ

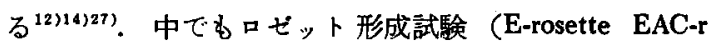
osette）による $\mathrm{T}$ 細胞 $\mathrm{B}$ 細胞の同定は，最近最も普及し た検査と言える.著者む，橋，石川らによるマイクロテ ストプレート法にてロぜット形成試験を行ったが，微量 検体で操作も簡単ならえ再現性む良好な結果を得てい る. 教室では, 長田 ${ }^{28)}$ の行った健康人症例 30 検体の $\mathrm{T}$ 細 胞比 $65 \pm 4 \% ， B$ 細胞 $35 \pm 6 \%$ 正常域としている. 諸 家の報告では，桥は $\mathrm{T}$ 細胞60～70\%， B 細胞30～50\%， 矢田は $\mathrm{T}$ 細胞 $40 \sim 60 \% ， \mathrm{~B}$ 細胞 $20 \sim 30 \% ，$ Ross は T 細胞 $65 \% ， \mathrm{~B}$ 細胞 $35 \% ，$ William は $\mathrm{T}$ 細胞 $75 \pm 15 \% ， \mathrm{~B}$ 細胞 $23 \pm 7 \%$ 正常域としている. 一方，担癌体に於いては $\mathrm{T}$ 細胞は低下していることが多く，教室の長田の検索で は，胃癌悪液質症例に於いては $\mathrm{T}$ 細胞比 $50 \pm 11 \%$ ，その 他の癌悪液質症例に於いては $\mathrm{T}$ 細胞比 $51 \pm 10 \%$ と 細胞 比の低下を認めている ${ }^{28)}$. 文献的にむ，肺癌，胃癌， 乳癌などの固型癌に於いての T 細胞比は低下の傾向にあ り, 特に癌腫の発育進行と共にその傾向は強い様であ る $^{29 / 301311}$. しかし，末期癌症例に於いても T細胞比が正 常値或は高值を示す症例もあり，Subpopulation のみで は充分な検索と言えず，そこに subsets 検索の必要性が 存在するわけである，担癌体に於いて，癌細胞障害とい った意味から Killer $\mathrm{T}$ 䋱胞の増加は有利なことで，逆 にこれら $\mathrm{T}$ 細胞に抑制的に働くSuppressor $\mathrm{T}$ 細胞の増 加は不利なことになる．近年この Suppressor $\mathrm{T}$ 細胞 は，IgG-Fc リセプターを有するといった考えから その検索が進められており, 癌の進行と IgG-Fc リセブ
タ一陽性 $\mathrm{T}$ 細胞との相関を得ている報告すある ${ }^{33)}$. 今後 リンパ球 subsets は充分な檢索を要求される分野であろ 5.

\section{第 2 項 遅延型皮庴反応の検索}

リンパ球 subpopulation 及び subsets，その他の細細性 免疫能の検索に比べ，遅延型皮唐反応は簡単な手技で細 胞性兔疫能の一指標が得 られ広く臨床に応用されてい る.この抗原としては, PPD, Candida albicans, Streptokinase, Streptodornase, Coccidioidin, Histoplasmin, Mumps, dermatophytin, tricophiton, 2-4dinitrochlorobe nzen (DNCB), dinitrofluorobenzen (DNFB), さらには 最近幄延型皮處反応と類似の反応を起すことが注目され てきた PHAなどがある. 古くから Hodgkin 病では革 延型皮膚反応の低下が明らかにされており ${ }^{34)}$, 又 Hughes らは年), 非癌患者の PPD 反応陽性率は81\%に対し, 癌 患者の陽性率は $52 \%$ と著明な反応低下が認められたと報 告している. 螺良らは要胃癌患者の病期別に PHA 反 応を検討し，癌の進行ととすに反応低下が顕著になると 報告している，著者の検索に於いても，切除不能癌及び 再発癌では，PPD 反応，PHA 反応ともに反応性低下は 著明であり，遅延型皮虎反応は，癌の病期をある程度反 映するすのと思われる，そこで著者は，治療前後に於け る $\mathrm{T}$ 細胞及び遅延型皮履反応を観察した。

\section{第 4 節 化学索法に於ける細胞性免疫能の变動}

近年の癌化学療法は，薬剤の開発，投与形式，併用薬 剤の改善などにより著しい進歩を逐げている，制癌剤の 目的は，いずれにせよ腫湯緗胞壊死を期待することであ るが，腫場細胞のみを選択的に破壊するるのではなく， 同時に正常細胞にも作用するので両者の量的差異を利用 して抗癌効果を期待するものである. 当然, 免疫担当細 胞にも大なり小なりその影響が出てくると考えられる. 著者の臨床経験からも，制癌剂特に多剂併用投与により 尰葲縮少効果は認められるる生存日数はむしろ短縮した り，逆に尰湯増殖が促進する症例もみられ，背景には制 癌剤による免疫抑制が関与しているのではないかと思わ れる. $\mathrm{T}$ 細胞及び遅延型皮底反応で細胞性免疫能を検索 した著者の実験結果では，図3に示す如く単剂化学療法 $\mathrm{F}$ 群では， $\mathrm{T}$ 細胞比及び $\mathrm{T}$ 細胞絶対数は投与後低下の傾 向を示したか，PPD 反応，PHA 反応 では，投与前後 に有意な変動は認められなかった。多剤併用投与に上る MF 群では，図4 に示す如く $\mathrm{T}$ 細胞及び遅延型皮庙反応 ともに投与後值は低下を示した.このことは，単昘化学 療法に比べ多剤化学療法に於いて細胞性兔疫能は低下す 
ることを示唆している．しかし，担癌体は免疫不全を基 盤之考えるならば，薬郕投与前の宿主の状態む考感に入 れなければならない，图5，図6に示寸如く，切除別に T細胞，PPD 反応，PHA 反応の変化をみると，治瘾切 除例では投与前の值は高く, 又投与後の反応も著明な変 化をとらなかった、すなわち, 主腫瘍を完全に切除する ことにより免疫不全の状態が改善され，細胞性免疫は保 持されていると考兄られる. しかし，畽掦の残存する非 治空切除, 非切除, 再発症例では, 死亡例も多く, 化学 療法炕よって細胞性免疫能は低下を示した. このこと は, 正常細胞之の量的差異を利用した抗癌効果は発揮で きず，むしろ制癌剤により免疫不全状態に拍車をかけた ことも考えられる. 文献的にも制癌剂による免疫能低下 の報告は多く，久野は ${ }^{37}$ 動物実験に於いて，FT-207は 胸腺細胞に与える影笠が強く, 特に, helper T cell へ の抑制が示唆され，MMCはT 細胞のやや増加を認める るPHA による反応性 低下すると報告している. 又 5Fu 几於いては抗体産生能を低下させ ${ }^{38)}$, PHA 及び PPD に対する反応性が低下する報告すある ${ }^{39}$ ．逆に5Fu

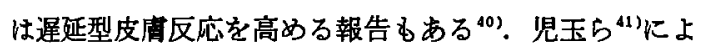
れば，実験腫瘍に於いて，MMC，5Fu，FT-207は非投与 群に比べ早い時期に MIF 活性が認められ，この時期に 一致して一時的に属煬は縮少するが，早晚 MIF 活性は 陰性化し盾瘍は增大寸ると報告している.この様に制癌 剤の免疫抑制が考えられるならば，制癌剤投与は担癌体 の免疫能を充分把握し，極力癌細胞を排除し免疫系への 影響を最少限にし，抗癌効果を発揮できる投与方法が理 想と考えるが，現在の制癌㓮では十分と言えず，大きな 抗癌効果を期待す机ば免疫系の影響が強く出現する. 従 って何とか危疫能の保持向上を考虑すれば，近年注目を 浴びている免疫㞠法との併用が現状に於ける大きな一手 段であろら.

\section{第 5 節 兔疫電法に於ける細胞性兔疫能の変動}

癌の免疫療法の歴史は古く42), 寸でに80年余を経過し ている. しかし，近年に至るまで癌治療の主役は，手術 療法, 放射線療法, 化学療法であったが, 瘇煌免疫学の 発達, さらには既存療法による癌治療の行き詰りにも上 り, 再び免疫療法が脚光を浴びるようになった. 危疫療 法は大別すると, active immunotherapy, passive immunotherapy, nonspecific immunotherapy, に分けられ ${ }^{43}$, 靦在広く臨床に応用されているのは免度賦活剂を用い た nonspecific immunotherapy であり，BCG が中心に 行われてきたが，近年に於いては，OK432，PSK，レバ
ミソール, レンテナン等数多くの免疫賦活片が開発され 臨床に応用されている. 著者す OK-432を用いて免疫療 法を施行し, 細胞性免疫能の变動を $\mathrm{T}$ 細胞及び遅延型皮 庙反応で愉討した結果, 图 7に示す如く, $\mathrm{T}$ 細胞比, $\mathrm{T}$ 細胞絶対数の上昇， PPD 反応，PHA 反応の增強が認 められた. しかし，全ての症例汇反応增強が認められる 訳ではなく, 図8, 図9に示す如く, 治窵切除例及び非

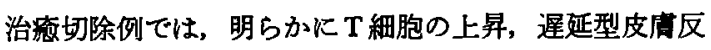
応は增強し，制癌剂投与にてその細胞性免疫能の低下し た非治症切除例に於いても OK-432によって兔疫能は保 持向上されている. しかし主腫湯の残存する非切除例で は全例死亡例で，T細胞比の低下，PPD，PHA に対す る反応性の低下を示し, 免疫療法によってす免疫系への 補強は期待できなかった，このことは，免度療法の骨

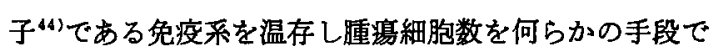
減少せしめ，少数の尰海細胞を選択的に生体の免疫力で 根治させるといった考えの裏づけの一つにるなると考え られれる.一般に OK-432の作用機序は, 網内系の賦活, 末梢白血球及びリンパ球数の增加，さらには腫湯細胞 に対する Cytocidal な効果などが挙げられている しかし，免疫療法による腫瘍細胞破壊は期待できず，担 癌体の免疫能向上をみても終局的には腫湯細胞の増殖は 抑えきれず転移增殖の結果となる。しかる，腫湯細胞は 絶えず免疫抑制因子を放出しており，免疫不全状態にさ らに拍車をかけることになる. そこで何らかの手段で腫 瘍細胞に Cytocidal な効果を期待し, 極力腫瘍細胞を減 少させた上での免疫療法が望まれる.

\section{第 6 節 兔疫化学暴法に於ける細胞性兔疫能の变功}

免疫不全を基盤としている担癌体に制癌㓣投与は時と して免疫不全状態に拍車をかけ腫晹增殖を余義なくされ ることもある.しかも，免疫療法による免疫系の補強の みでは，元来抗原性の低い担癌体自身での Cytocidal な 効果は十分と言えず，両者の相乗効果を期待した免疫化 学療法の導入が検討される.著者は, 図10に示す如く, $5 F u$ 或は FT-207に OK-432を併用した兔疫化学療法で の細胞性免疫能を検討してみた. 治療前後の $\mathrm{T}$ 細胞及び 遅延型皮唐反応の変動をみると, 治潦後,これらの值は 上昇しており, 生存例ではほとんど細胞性免度能は保持 向上されている事が示唆される. さらに MMC を併用 した多剂化学療法に免疫療法を併用してみると, 図11K 示す如く， $\mathrm{T}$ 細胞及び遅延型皮庴反応とも生存例では治 療後值は上昇しており, 制癌剤に上る細胞性免疫能の低 下は，OK-432 投与によって保持向上されたものと考え 
る.しかし，死亡例の多くは，細胞性免疫能は低下して おり，全てに有効であるとは言いがたく，切除別にみる

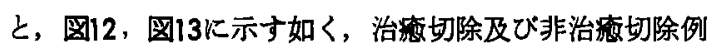
では，治療後 $\mathrm{T}$ 細胞比， $\mathrm{T}$ 細胞絶対数の上昇， PPD 反 応及び PHA 反応の増強が認められるが，非切除及び 再発症例で死亡例も多く，これらの反応は一定の㑯向 は示さず，むしろ低下の傾向にあった．化学療法単独に て細胞性免度能の低下を認めた非治殓切除例に於いて も，OK-432を併用することにより細胞性免疫能は保持 向上されている.このことは，制癌剤による殺腫晹効果 々免疫賦活㓮の免疫能向上の相乗効果が期待できたこと を示唆している. しかし, 主腫洗の残存する非切除例或 は再発例では，治療前すでに免疫不全状態の強い, 症例が 多く，免疫療法による免疫系の補強は十分と言えず，制 癌刘投与により殺腫痬効果はあったとしても，さらに兔 疫不全状態に拍車をかけたことも考えられよう。この様 に化学療法と免疫療法の併用は，両者の作用を相乗し， 現状では有意な療法と考えるが，治療前の細胞性免疫能 は十分に把握した上で治療は決定されなければならな く，今後免疫化学療法にあたり，その合併時期は充分考 虑されなければならないい?. 全ての担癌体に同じ投与形 式，投与方法，投与量といらのではなく，併用潦法にあ たって, 細胞性免疫能を十分把握して, 化学療法に比重 を扰くか，免疫療法に比重を拈くかを考麀しなければな らない.

\section{第 $\mathbf{V}$ 章 結 語}

胃癌患者を中心とした悪性腫瘍患者に, 化学療法, 免 疫療法, 免疫化学療法を行い, 治療前後の細胞性免疫能 を $\mathrm{T}$ 細胞比， $\mathrm{T}$ 細胞絶対数， PPD 反応 PHA 反応にて 観察し, 治療の選択, 予後の判定を中心に検討し, 下記 の結論を得た。

1) 担癌体の $\mathrm{T}$ 練胞の変動之 PPD 反応 PHA 反応 ははばパラレルに変動した。

2） $\mathrm{F}$ 群では， $\mathrm{T}$ 細胞比及び $\mathrm{T}$ 細胞䋓対数は薬郕投与 後低下する傾向にあるが，PPD 反応及び PHA 反応 は，あまり変化しない。

3） MF 群では，薬剂投与後 $\mathrm{T}$ 細胞比の低下， $\mathrm{T}$ 細胞 絶対数の減少，PPD 反応及び PHA 反応の低下を認め る.

4）治海切除例に於ける化学療法は，免疫系に著明な 変動を示さないが, 腫焬の残存する非治窑切除, 非切 除, 再発症例では, 化学療法によって細胞性免疫能は低 下する。
5） 0 群では， $T$ 細胞比の上昇， $T$ 細胞絶対数の增 加, PPD 及び PHA に対する反応性の増強を認める.

6）治复切除例に於ける免疫療法は，細胞性免疫能の 保持向上を期待できるが，非切除及び再発症例ではその 効果は期待できない。

7） FO 群及び MFO 群では，T細胞比の上昇 $\mathrm{T}$ 細 胞絶対数の增加，PPD 反応及び PHA 反応の増強を認 める.

8）免疫化学療法は, 制癌剤の殺厙瘍効果と免疫賦活 剂による免疫系補強の相乗効果が期待できる.しかし全 てに有効とは言えず，非切除及び再発应例では，その効 果は十分でない。

9）一般に, 化学療法, 免疫療法, 免疫化学療法施行 後， $\mathrm{T}$ 紐胞比の上昇 $\mathrm{T}$ 細胞絶対数の増加， PPD 反応及 び PHA 反応増強例は経過良好である.

10） $\mathrm{T}$ 細胞比 $55 \%$ 以下， $\mathrm{T}$ 細胞絶対数 600 個 $/ \mathrm{ml}$ 以下, PPD 反応 $5 \mathrm{~mm}$ 以下, PHA 反応 $10 \mathrm{~mm}$ 以下の 4 項目を 満す症例は，各療法とも有効之言えない。

11）化学療法, 免疫療法, 免疫化学療法にあたり, 紐 胞性免疫能を観察することは, 治療の方針, 薬凧の投与 量及び投与方法の選択, 予後判定の大きな指標となる.

稿を終るにあたり，御校閲をいただきしした恩師牧野 惟義教授に深く感謝の意を表します，又，本研究に御理 解，御援助を睗つた永井純義教授に感揤致すとともに， 䅂始、御指導、御教示いただきしたた相馬哲夫教授，大 石山助教授，小沢靖講師，井上仁潇師に深く感謝いたし ます、又, 研究に御協力いただきした教室諸先生方に む心から感謝いたします。

なお，本論文の要旨は下記の学会に於いて発表した。 第15回 日本瘦治療学会総会

第19回日本消化器病学会

第11回 日本消化器外科学会総会

第99回 東京医科大学医学会総会

\section{美考文献}

1) 菊地浩吉, 森 道夫, 今村正克: 医科免疫学, 250-252, 南江堂, 1976.

2）森沢成司：活性化リンパ 球の産生する Chemical mediator リンホカイン, 日本臨床, $36: 5$, 23-29, 1978.

3) 服部孝雄 : がんの免疫化学療法, 癌上化学療 法, $2: 1,9-12,1975$.

4) Foley, E.J.: Antigenic properties of methylcholanthrene induced tumors in mice of the 
strain of organ. Cancer. Res., 13: 835-837, 1975.

5) Klein, G., Sjögren, H.O., Klein, E. et al.: Demonstration of resistance against methylcolanthrene induced sarcoma in the primary autochthonous host. Cancer. Res., 20: 1561$1572,1960$.

6) L.J. Old: Cancer immunology. Scientific American (日本版) 19:26-41, 1977.

7) 菊地浩吉, 森 道夫, 今村正克他 : 医科免疫 学, 南江堂, 1976.

8）森 武貞, 中田俊平：人瘦之免疫，61-66, ラ イフサイエンス, 1976.

9) Fefer, A.: Studies on the growth and regression of a transplantable moloney sarcoma. Cancer. Res., 27 : 2707, 1967.

10) Hoover, R. and Fraumeni, J.F. Jr.: Risk of cancer in renaltransplant recipients. Lancet., 2: 55-57, 1973.

11) Burnet, F.M.: Immunological Surveillance. 1970. Pergamon Oxford.

12）矢田純一：Tリンパ球と B リンパ球, 中外医学 多書, 1975.

13) 藤井源七郎, 関口守正, 長田 功他 : 担癌体の 細胞性免疫，医学のあゆみ，91：9，400-405, 1974.

14）㛢 武彦: 人癌と免疫，19-39, ライフサイェ ソス, 1976.

15）橋本嘉幸 : 癌の発生と免疫機構，臨床医， 2 : 9, 120-122, 1976.

16) 徳永 徹: BCG の抗腫陽作用のメカニズム,最 新医学, $33: 8,1513-1520,1978$.

17) 霞 武彦, 小林 博 : 尰瘍免疫学, 朝倉書店, 1975.

18) Roitt, I.M.: Lancet, ii : 376-371, 1967.

19）檑 武彦：ヒトの T cell と B cell の分離法 ならびに surface makerによる数の算定法, 日 本臨床, 33:1，221-233，1975.

20) 榣 武彦: $\mathrm{T}$ 細胞と $\mathrm{B}$ 細胞, 臨床兔度, $9: 2$, $118-127,1977$.

21) Waltraut H. Lay and Nelson F. Mendes: Binding of sheep red blood cells to a larger population of human lymphocytes. Nature.,
230, 23 : $531-532,1975$.

22) Y. Ishii, H. Koshiba, H. Ueno, et al.: Surface antigenic specificities of human thymusderived lymphocytes. Clin Exp. Immunol., 19: 67-74, 1975.

23) J. Yata, I. Tsukimoto and T. Tachibana: Human lymphocyte subpopulations. Human thymus-lymphoid tissue (HTL) antigen-positive lymphocytes forming rosettes with sheeperythrocytes and HTL antigen-negative lymphocytes interacting with antigen-antibodycomplement complexes. Clin Exp. Immunol., 14: 319-326, 1973.

24) Celso Bianco: Theta-bearing and complementreceptor lymphocytes are distinct population of cells. Science., 173: 154-156, 1971.

25) Fröland, S. and Nativig, B.J.: Surface-bound immunoglobulin as a marker of B lymphocytes in man. Nature New Biology, 234: 251-252, 1971.

26) 小坂昌明：白根 暞, 三好和夫他：リンパ球 の表面 Ig および内部 Ig 臨床病理, XXV 7 : $547-553,1976$.

27) 矢田純一 : T cell $と$ B cell. medicina 13, 9 : $14-17,1976$.

28）長田省一，田㴊崇文，相馬哲夫他：悪性疾患患 者に於ける $\mathrm{T}$ cell の動態, 最新医学, 32 : 12, 2361-2367, 1977.

29) A. Lee Dellon, Claude Potvin and Paul B. Chretien: Thymusdependent lymphocyte levels in bronchogenic carcinoma: Correlations with histology, clinical stage, and clinical course after surgical treatment. Cancer., 32, 3: $687-694,1975$.

30) Wybran, J. and Fudenberg, H.H.: Thymusderived rossete-forming cells in various human disease states: Cancer, lymphoma bacterial and viral infections and other diseases. J. Clin. Invest., 52: 1026-1032, 1973.

31) Anthony, H.M., Kirk, J.A., Madsen, K.E. et al.: $\mathrm{E}$ and EAC rosetting lymphocytes in patients with carcinoma of bronchus. Clin. Exp. Immunol., 20: 41-54, 1975. 
32) Herzenberg, L.A., K. Okumura, Cantor, H. et al.: T-cell regulation of antibody responses: Demonstration of allotype-specific helper $T$ cells and their specific removal by suppressor T cells. J. Exp. Med., 144: 330—334, 1976.

33）麦谷瞳夫, 成木行彦, 大塚幸雄他 : 消化器悪性 尰瘍の治療に和ける $\mathrm{T}$ 細胞の変動, 日本癌治療 学会誌, $13: 1,12-19,1978$.

34) Alan C. Aisenberg: Studies on delayed hypersensitivity in Hodgkin's disease. J. Clin. Invest., 41, II : 1964-1970, 1962.

35) L.E. Hughes, and W.D. Mackay, : Suppression of the tuberculin response in malignant disease. Brit. Med. J., 2 : 1346, 1965.

36）螺良英郎，矢田健太郎，小川紘一他：癌患者免 疫能の診断パラメーター, 癌と化学療法, 4： $4,43-61,1977$.

37）久野悟郎, 富永憲治, 螺良英郎他：制癌剤及び 免疫抑制因子のリンパ系細胞及び抗体産生に 及ぼす埧響, 癌と化学療法, 2 : 1, 59-66, 1975.

38) M.C. Berenbaum,: A Screen for Agents inhibiting the Immune Response and Gorwth of Tumours. Nature., 196, 1962.
39) E. Nordman, H. Saarimaa and Toivanen, A.: The influence of 5-fluorouracil on cellular and humoral immunity in cancer patient. Cancer., $41: 64-69,1978$.

40) Blomgren, S.E.: Can Res, 25: 977, 1965.

41）児玉 宏, 大垣和久, 日笠頼則 他：制癌風の 免疫抑制作用の検討, 癌之化学療法, $3: 2$, $105-110,1976$.

42) Currie, G.A.: Eighty years of immunotherapy, a review of immunological methods used for the treatment of human cancer. $\mathrm{Br}$. J. Cancer., 26: $141,1972$.

43) 東 市郎：人癌と免疫, ライフサイエンス, 1976.

44）折田蒸三：免疫療法へのアプローチ, 総合臨 床, $26: 2,310-318,1977$.

45）小川一誠：免疫療法，月刊薬事，19：1，75一 78, 1977.

46) 木村郁郎：溶連菌剤 OK-432 と癌が免疫化学療 法の 可能性, 癌と 化学療法, 2: 1, 21-23, 1975.

47) 細川真澄男, 水島 豊, 小林 博他 : 癌の免疫 および化学療法に括ける合併時期の問題点, 癌 と化学療法, 5：6, 13-19, 1974. 